\title{
Impact of the SARS-CoV-2 Pandemic and First Lockdown on Pregnancy Monitoring in France: the COVIMATER Cross-sectional Study
}

\author{
Alexandra Doncarli ( $\sim$ Alexandra.DONCARLI@santepubliquefrance.fr ) \\ Non-Communicable Diseases and Trauma Division, Santé publique France, Saint-Maurice, France \\ Lucia Araujo \\ Non-Communicable Diseases and Trauma Division, Santé publique France, Saint-Maurice, France
}

Catherine Crenn-Hebert

Department of Gynecology and Obstetrics, Louis Mourier University Hospital, AP-HP, Colombes, France

\section{Virginie Demiguel}

Non-Communicable Diseases and Trauma Division, Santé publique France, Saint-Maurice, France

\section{Julie Boudet-Berquier}

Non-Communicable Diseases and Trauma Division, Santé publique France, Saint-Maurice, France

\section{Yaya Barry}

Non-Communicable Diseases and Trauma Division, Santé publique France, Saint-Maurice, France

\section{Maria-Eugênia Gomes Do Espirito Santo}

Non-Communicable Diseases and Trauma Division, Santé publique France, Saint-Maurice, France

\section{Andrea Guajardo}

Data processing, support and analysis department, Santé publique France, Saint-Maurice, France

Claudie Menguy

Non-Communicable Diseases and Trauma Division, Santé publique France, Saint-Maurice, France Anouk Tabaï

Alert and crisis department, Santé publique France, Saint-Maurice, France

\section{Karine Wyndels}

Santé Publique France, Hauts-de-France regional office, Saint-Maurice, France

\section{Alexandra Benachi}

Division of Obstetrics and Gynecology, Antoine Béclère Hospital, AP-HP, Clamart, France

\section{Nolwenn Regnault}

Non-Communicable Diseases and Trauma Division, Santé publique France, Saint-Maurice, France

\section{Research Article}

Keywords: pregnant women, SARS-CoV-2, lockdown, pregnancy monitoring 
Posted Date: June 30th, 2021

DOl: https://doi.org/10.21203/rs.3.rs-601913/v1

License: (c) (i) This work is licensed under a Creative Commons Attribution 4.0 International License. Read Full License

Version of Record: A version of this preprint was published at BMC Pregnancy and Childbirth on November 30th, 2021. See the published version at https://doi.org/10.1186/s12884-021-04256-9. 


\section{Abstract}

\section{Background}

In the context of the SARS-CoV-2 pandemic, consultations and pregnancy monitoring examinations had to be reorganised urgently. In addition, women themselves may have postponed or cancelled their medical monitoring for organisational reasons, for fear of contracting the disease caused by SARS-CoV-2 (Covid-19) or for other reasons of their own. Delayed care can have deleterious consequences for both the mother and the child. Our objective was therefore to study the impact of the SARS-CoV-2 pandemic and the first lockdown in France on voluntary changes by pregnant women in the medical monitoring of their pregnancy and the associated factors.

\section{Methods}

A cross-sectional study was conducted in July 2020 using a web-questionnaire completed by 500 adult (>18 years old) pregnant women during the first French lockdown (March-May 2020). A robust variance Poisson regression model was used to estimate adjusted prevalence ratios (aPRs).

\section{Results}

Almost one women of five (23.4\%) reported having voluntarily postponed or foregone at least one consultation or pregnancy check-up during the lockdown. Women who were professionally inactive (aPR=1.98, Cl95\%[1.24-3.16]), who had experienced serious disputes or violence during the lockdown (1.47, [1.00-2.16]), who felt they received little or no support (1.71, [1.07-2.71]), and those who changed health professionals during the lockdown (1.57, [1.04-2.36]) were all more likely to have voluntarily changed their pregnancy monitoring. Higher level of worry about the pandemic was associated with a lower probability of voluntarily changing pregnancy monitoring $(0.66,[0.46-0.96])$.

\section{Conclusions}

Our results can guide prevention and support policies for pregnant women in the current and future pandemics.

\section{Introduction}

Data from previous coronavirus outbreaks in 2002 and 2013 showed that pregnancy was a risk factor for severe forms of associated respiratory diseases. More specifically, SARS-CoV-1 and MERS-CoV were associated with significant acute respiratory distress syndrome $(1,2)$. This fact, together with recommendations of learned societies $(3,4)$, prompted several countries, including France, to declare in March/April 2020 that pregnant women should be considered a population at greater risk of severe forms of COVID-19, the disease caused by SARS-CoV-2 (5-9). In the absence of vaccines and effective pharmaceutical treatments at that time, most governments decided to reduce the spread of the virus by implementing strict lockdowns of their entire population for several months. These actions together with 
to the increased influx of patients suffering from COVID-19 brought about major changes in the organisation of health systems $(10,11)$, including the organisation of hospital gynaecological departments (10-12). In the United States (U.S.) a longitudinal study reported a decrease of $20 \%$ in onsite abortion during the first trimester of pregnancy between February and June 2020. In addition, a decrease in on-site consultations for abortion follow-up was observed, prompting an increase in teleconsultations and medical abortion at home (12). Another U.S. study, conducted between mid-March and mid-May 2020 showed that nearly one-third of pregnancy monitoring visits were modified, cancelled or rescheduled (13). In France, a longitudinal study on the surgical management of gynaecological cancers reported a change in medical management for $27 \%$ of its participants, including $23.2 \%$ for whom surgery was either postponed or cancelled due to the influx of patients infected with SARS-CoV-2 during the first lockdown (14), which took place between 17 March and 11 May 2020.

With regard to pregnancy, monitoring consultations were initially deprogrammed by French health professionals before official guidelines recommended that follow-up be maintained and reorganised $(15,16)$. The French healthcare system adapted very quickly to the crisis, offering $100 \%$ reimbursed tailored teleconsultation (video and telephone-based consultations) to pregnant women (21). Maternity wards and private offices also changed pregnancy monitoring practices. More specifically, partners were not allowed to be present during consultations, obstetric examinations or during hospitalization for childbirth, except under certain conditions (18). Only partners were allowed to visit after childbirth $(15,18)$.

In addition to the reorganisation of the health sector, some women voluntarily (i.e., spontaneously) modified their medical monitoring for different reasons, for example organisational scheduling $(16,19)$.

Any postponement or foregoing of consultations or examinations in the context of pregnancy is of particular concern for the health of both the mother and child, as screening must be performed within specific time windows (24). More specifically, failure to monitor foetal weight gain, screen for gestational diabetes and hypertension, has deleterious consequences for the newborn (25-28).

In the context of the SARS-CoV-2 pandemic, it is essential that the health management of pregnant women be continually adapted to best meet the changing needs in this dynamic context. To do this, it is necessary to understand the reasons why pregnant women voluntarily change their pregnancy monitoring.

Our objective was to study i) the effects of the SARS-CoV-2 pandemic and France's first associated lockdown on the frequency of voluntary changes in pregnancy monitoring by women during the country's first lockdown, and ii) associated factors.

\section{Methods}

\section{Population and data source (Covimater)}


From an internet access panel of volunteer internet users (BVA group), we created a non-probability study (Covimater) sample of 500 adult women who were pregnant during the first lockdown in France (17 March - 11 May 2020). Participants were 18 years old and over and residents in metropolitan France. Women who gave birth in the two first weeks of the lockdown and those whose pregnancy began during the last two weeks were not included due to their limited exposure to it. Eligible women were invited to answer a web-based questionnaire between 6 and 20 July 2020 .

\section{Survey methodology}

Covimater used quotas sampling, whereby the study sample is assigned a structure similar to that of the target population (i.e., all pregnant women) in order to tend towards representativeness. The population of parents of children under one year old - as per the National Institute of Statistics and Economic Studies 2016 census - was used to obtain the quotas (25). Only mothers' quotas were used to calculate weightings using Newton's algorithm (26). Specifically, these data comprised age group, socioprofessional category (SPC), region of residence, size of urban area, and parity. No significant difference in age group, region of residence or parity was observed between women participating in Covimater and the whole population of women in France who gave birth in a hospital maternity ward (i.e., $99 \%$ of French pregnant women population (27)).

\section{Changes in pregnancy monitoring at the initiative of pregnant women}

For the present study, women who voluntarily changed their pregnancy monitoring during the lockdown were defined as those who reported at least one of the following in the questionnaire: (i) foregoing pregnancy examinations, (ii) voluntarily postponing or cancelling pregnancy consultations, (iii) delaying the start of monitoring (i.e., not starting monitoring despite a gestational age of over 15 weeks) (27).

The reasons for changes in pregnancy monitoring were explored through 13 binary questionnaire items covering different themes (lockdown, SARS-CoV-2 infection, and organisational problems, specifically personal and healthcare-based).

\section{Covariates}

Explanatory variables were divided into five main themes:

Socio-demographic: age, country of birth, socio-professional category (SPC) reduced into SPC+ (selfemployed women, managers, intermediate professions), SPC- (employees, blue-collar workers) and Inactive (students and other professionally inactives), education level, the perception of their financial situation, having in the household during the lockdown, a partner and/or one or more children under the age of six, size of urban area and geographical area of residence according to the level of active circulation of the virus and strain on hospital intensive care unit capacity in May 2020 (four coloursaccording to increasing epidemic pressure on the healthcare system) (28). 
Lockdown-related: workload, access to a private or common outdoor space, level of knowledge about the virus' modes of transmission, self-perceived social support (i.e., from family, friends, etc.), having experienced serious arguments and/or a climate of violence, having symptoms which led the participant to think they had COVID-19, having loved ones who had either been diagnosed with COVID-19 or had symptoms suggestive of the disease.

Perception of the epidemic: participants' perceived general worry about the pandemic situation in France (scale from 0 , not at all worried to 10 , very worried).

Pregnancy and health: parity, gestational age at the end of lockdown or at the time of the questionnaire, at least one pre-existing chronic pathology or pregnancy-related pathology, overweightness/obesity (Body Mass Index $=>25 \mathrm{~kg} / \mathrm{m}^{2}$ ).

Healthcare during lockdown: unsuccessful attempts to have an exchange with healthcare professionals about the pregnancy and the pandemic, having been followed by a professional other than the usual one, having teleconsultations (video or telephone), having childbirth preparation sessions, having at least one pregnancy check-up or consultation due to pandemic-related restrictions the participant's partner or person providing support during pregnancy was not allowed to attend.

\section{Statistical analysis}

A robust variance Poisson regression model was used to estimate unadjusted and adjusted prevalence ratios (aPR) (29) for voluntary changes in pregnancy monitoring. Factors associated with this outcome which had a p-value $<0.20$ in bivariate analysis or which were judged to be clinically relevant based on the literature (gestational age at the time the study questionnaire was completed, gestational age at the end of the lockdown period, parity) were introduced into the multivariate model. When several variables were possibly collinear, the model with the best likelihood score (lowest Bayesian Information Criterion) was selected. Fractional polynomials showed a linear relationship between continuous variables included in the models and the studied prevalence of the outcome. The final model included the variables independently associated with the variable of interest ( $p$-value $<0.05)$ after epidemiological reflection and according to the clinical relevance of each variable at each step of the procedure. A manual stepwise descending approach was applied.

Estimates of aPR, their $95 \%$ confidence intervals $(95 \% \mathrm{Cl})$ and associated $\mathrm{p}$-values were presented. As indicated by Zou, PRs are interpreted in the same way as relative risks (30).

All statistical analyses were performed using Stata software ®version 14.2 (Stata Corp., College Station, TX, USA).

\section{Results}

Characteristics of women included in Covimater (Table 1) 
The mean age was of the Covimater study sample $(n=500)$ was 31.4 years $(s d=5.1)$. Four-fifths $(78.1 \%)$ had a secondary school diploma or higher level of education, $36.1 \%$ were classified SPC-, $25.5 \%$ were Inactive, $31.7 \%$ declared they just got by financially, while $19.1 \%$ reported that they could not make ends meet. 
Table 1

Description of pregnant women during the first COVID-19-related lockdown (March to May 2020) who participated in the Covimater survey $(n=500)$, France, (July 2020)

\begin{tabular}{|c|c|c|c|}
\hline & \multicolumn{2}{|c|}{$N(\%) *$} & $95 \% \mathrm{Cl} *$ \\
\hline \multicolumn{4}{|c|}{ Socio-demographic characteristics and variables related to the first lockdown } \\
\hline \multicolumn{4}{|l|}{ Age (in years) } \\
\hline $18-24$ & 53 & $(10.7)$ & $\begin{array}{l}7.4- \\
15.2\end{array}$ \\
\hline $25-34$ & 323 & $(64.6)$ & $\begin{array}{l}59.7- \\
69.2\end{array}$ \\
\hline $35-49$ & 124 & $(24.7)$ & $\begin{array}{l}21.1- \\
28.8\end{array}$ \\
\hline \multicolumn{4}{|l|}{ Socio-professional category (SPC) ${ }^{\star \star}$} \\
\hline $\mathrm{SPC}+$ & 192 & $(38.4)$ & $\begin{array}{l}33.9- \\
43.2\end{array}$ \\
\hline SPC - & 180 & $(36.1)$ & $\begin{array}{l}31.8- \\
40.6\end{array}$ \\
\hline Inactive & 128 & $(25.5)$ & $\begin{array}{l}20.5- \\
31.2\end{array}$ \\
\hline \multicolumn{4}{|l|}{ Educational level } \\
\hline Equal to or higher than secondary school diploma & 391 & $(78.1)$ & $\begin{array}{l}73.6- \\
82.1\end{array}$ \\
\hline Lower than secondary school diploma & 109 & $(21.9)$ & $\begin{array}{l}17.9- \\
26.4\end{array}$ \\
\hline \multicolumn{4}{|l|}{ Perceived financial situation } \\
\hline Comfortable & 246 & $(49.2)$ & $\begin{array}{l}44.2- \\
54.2\end{array}$ \\
\hline Just getting by & 159 & (31.7) & $\begin{array}{l}27.2- \\
36.6\end{array}$ \\
\hline Difficult to make ends meet & 95 & $(19.1)$ & $\begin{array}{l}15.2- \\
23.7\end{array}$ \\
\hline Social Security Healthcare Insurance & 494 & $(98.7)$ & $\begin{array}{l}96.9- \\
99.5\end{array}$ \\
\hline \multicolumn{4}{|c|}{$\begin{array}{l}\text { Region of residence according to SARS-CoV-2 healthcare system severity } \\
\text { (colour-coded ) }\end{array}$} \\
\hline Green zone & 127 & $(25.4)$ & $\begin{array}{l}21.1- \\
30.2\end{array}$ \\
\hline
\end{tabular}




\begin{tabular}{|c|c|c|c|}
\hline \multirow[b]{2}{*}{ Orange zone } & \multicolumn{2}{|c|}{$\mathbf{N}(\%) *$} & \multirow{2}{*}{$\begin{array}{l}95 \% \text { Cl* } \\
25.7- \\
34.7\end{array}$} \\
\hline & 150 & $(30.0)$ & \\
\hline Red zone & 223 & $(44.6)$ & $\begin{array}{l}39.7- \\
49.6\end{array}$ \\
\hline Child(ren) under 6 years of age in the household during the lockdown & 234 & $(46.8)$ & $\begin{array}{l}41.8- \\
51.8\end{array}$ \\
\hline \multicolumn{4}{|l|}{ Working conditions during the lockdown $(n=386)^{\star \star \star \star}$} \\
\hline Working from home & 96 & $(24.8)$ & $\begin{array}{l}20.7- \\
29.4\end{array}$ \\
\hline Working in the usual place of work & 43 & $(11.3)$ & $\begin{array}{l}8.5- \\
14.7\end{array}$ \\
\hline Working from home and at the usual place of work & 10 & $(2.6)$ & $\begin{array}{l}1.5- \\
4.5\end{array}$ \\
\hline Did not work because unemployed (partially or not) & 65 & $(16.7)$ & $\begin{array}{l}13.4- \\
20.6\end{array}$ \\
\hline Did not work for other reasons (maternity leave, etc.) & 158 & $(40.9)$ & $\begin{array}{l}36.0- \\
46.0\end{array}$ \\
\hline Other situation & 14 & $(3.7)$ & $\begin{array}{l}1.9- \\
7.2\end{array}$ \\
\hline \multicolumn{4}{|l|}{ Workload during the lockdown } \\
\hline Did not work & 351 & $(70.1)$ & $\begin{array}{l}65.7- \\
74.2\end{array}$ \\
\hline Lighter or same as usual & 85 & $(17.1)$ & $\begin{array}{l}14.0- \\
20.7\end{array}$ \\
\hline Heavier than usual & 64 & $(12.8)$ & $\begin{array}{l}10.1- \\
16.0\end{array}$ \\
\hline Access to a private or common outdoor space during the lockdown & 434 & $(86.8)$ & $\begin{array}{l}82.8- \\
90.1\end{array}$ \\
\hline Lived with the same people during the lockdown $(n=488)^{\star \star \star \star}$ & 472 & $(96.8)$ & $\begin{array}{l}93.7- \\
98.4\end{array}$ \\
\hline Lived in the same dwelling during the lockdown & 478 & $(95.7)$ & $\begin{array}{l}93.2- \\
97.2\end{array}$ \\
\hline \multicolumn{4}{|l|}{ Self-perceived social support during the lockdown } \\
\hline Very good & 180 & $(36.0)$ & $\begin{array}{l}31.3- \\
40.9\end{array}$ \\
\hline
\end{tabular}




\begin{tabular}{|c|c|c|c|}
\hline \multirow[b]{2}{*}{ Good } & \multicolumn{2}{|c|}{$\mathbf{N}(\%) *$} & \multirow{2}{*}{$\begin{array}{l}95 \% \mathrm{Cl} * \\
41.2- \\
51.1\end{array}$} \\
\hline & 231 & $(46.1)$ & \\
\hline Little or none & 89 & $(17.9)$ & $\begin{array}{l}14.5- \\
21.8\end{array}$ \\
\hline \multicolumn{4}{|l|}{ Serious disputes or violence during first lockdown } \\
\hline Yes & 11 & $(2.3)$ & $\begin{array}{l}1.1- \\
4.6\end{array}$ \\
\hline Sometimes / Rarely & 129 & $(25.8)$ & $\begin{array}{l}21.7- \\
30.4\end{array}$ \\
\hline Never & 360 & $(71.9)$ & $\begin{array}{l}67.2- \\
76.2\end{array}$ \\
\hline \multicolumn{4}{|l|}{ Level of knowledge about SARS-CoV-2 transmission } \\
\hline Low & 14 & $(2.8)$ & $\begin{array}{l}1.5- \\
5.2\end{array}$ \\
\hline Medium & 35 & $(7.0)$ & $\begin{array}{l}4.8- \\
10.1\end{array}$ \\
\hline High & 451 & $(90.2)$ & $\begin{array}{l}86.7- \\
92.9\end{array}$ \\
\hline $\begin{array}{l}\text { General concern score for the SARS-CoV-2 pandemic } \\
(\max .10 ; n=485)>7 / 10^{\star \star \star \star \#}\end{array}$ & 234 & $(48.3)$ & $\begin{array}{l}43.3- \\
53.3\end{array}$ \\
\hline $\begin{array}{l}\text { Family member or friends diagnosed with COVID-19 or had symptoms } \\
\text { suggestive of the disease }\end{array}$ & 171 & $(34.2)$ & $\begin{array}{l}29.7- \\
39.0\end{array}$ \\
\hline Having had COVID-19 type symptoms & 92 & $(18.4)$ & $\begin{array}{l}14.9- \\
22.6\end{array}$ \\
\hline \multicolumn{4}{|l|}{ Clinical characteristics } \\
\hline Primiparous & 203 & $(40.6)$ & $\begin{array}{l}35.8- \\
45.6\end{array}$ \\
\hline \multicolumn{4}{|l|}{ Gestational age (weeks) at the end of first lockdown } \\
\hline$<10$ & 34 & (6.8) & $\begin{array}{l}4.7- \\
9.8\end{array}$ \\
\hline $10-20$ & 177 & (35.4) & $\begin{array}{l}30.8- \\
40.3\end{array}$ \\
\hline $20-30$ & 180 & (36.1) & $\begin{array}{l}31.4- \\
41.0\end{array}$ \\
\hline
\end{tabular}




\begin{tabular}{|c|c|c|c|}
\hline \multirow[b]{2}{*}{$30-40$} & \multicolumn{2}{|c|}{$\mathbf{N}(\%) *$} & \multirow{2}{*}{$\begin{array}{l}95 \% \text { Cl* } \\
12.1- \\
19.4\end{array}$} \\
\hline & 77 & $(15.4)$ & \\
\hline$>40$ & 32 & $(6.3)$ & $\begin{array}{l}4.3- \\
9.2\end{array}$ \\
\hline \multicolumn{4}{|l|}{ Childbirth } \\
\hline During lockdown & 34 & $(6.8)$ & $\begin{array}{l}4.7- \\
9.8\end{array}$ \\
\hline After lockdown & 466 & $(93.2)$ & $\begin{array}{l}90.2- \\
95.2\end{array}$ \\
\hline Pre-existing Chronic disease(s) & 152 & $(30.3)$ & $\begin{array}{l}25.8- \\
35.1\end{array}$ \\
\hline Overweight/Obesity & 212 & $(42.4)$ & $\begin{array}{l}37.5- \\
47.4\end{array}$ \\
\hline Pregnancy-related pathology(ies) & 119 & $(23.7)$ & $\begin{array}{l}19.9- \\
28.0\end{array}$ \\
\hline \multicolumn{4}{|l|}{ Pregnancy monitoring } \\
\hline Teleconsultations (video or telephone) for pregnancy monitoring & 197 & $(39.4)$ & $\begin{array}{l}34.6- \\
44.4\end{array}$ \\
\hline Change of health professional & 74 & $(14.9)$ & $\begin{array}{l}11.7- \\
18.8\end{array}$ \\
\hline Childbirth preparation sessions (video or telephone) & 76 & $(15.2)$ & $\begin{array}{l}12.0- \\
19.1\end{array}$ \\
\hline $\begin{array}{l}\text { Absence of partner/person providing support from a } \\
\text { consultation/examination }\end{array}$ & 459 & $(91.8)$ & $\begin{array}{l}88.8- \\
94.1\end{array}$ \\
\hline $\begin{array}{l}\text { Modification } \$ \text { of pregnancy monitoring at the initiative of a health } \\
\text { professional }\end{array}$ & 182 & $(36.3)$ & $\begin{array}{l}31.6 \\
-41.3\end{array}$ \\
\hline Modification $\$ \$$ of pregnancy monitoring at the initiative of the women & 117 & $(23.4)$ & $\begin{array}{l}18.8- \\
27.7\end{array}$ \\
\hline \multicolumn{4}{|l|}{ * Weighted and rounded values using Newton's algorithm (26) } \\
\hline \multicolumn{4}{|c|}{$\begin{array}{l}\text { ** Women on maternity leave and unemployed women were classified according to their current SPC } \\
\text { category or their most recent category prior to ending work, respectively }\end{array}$} \\
\hline \multicolumn{4}{|l|}{$\star \star \star$ Pressure on the healthcare system as of $01 / 05 / 2020$} \\
\hline \multicolumn{4}{|c|}{$\star \star \star \star$ Analysis performed in a sub-group of pregnant women depending on their previous answers } \\
\hline
\end{tabular}


\$ Postponing/cancelling pregnancy monitoring

\$ Postponing/foregoing /not starting monitoring despite a gestational age of 15 weeks (see definition of the variable of interest in Methods section).

From a medical perspective, $42.4 \%$ had overweight or obesity before pregnancy, and $23.7 \%$ had pregnancy-related pathologies, notably gestational diabetes (12.6\%), preterm labour (5.9\%), and gestational hypertension (1.6\%). Finally, $17.9 \%$ perceived receiving little or no social support during the lockdown, and nearly $28 \%$ experienced serious arguments and/or a climate of violence during the same period.

\section{Pregnancy monitoring during the first lockdown (Table 1)}

A total of $14.9 \%$ of women reported that they had been followed by a professional other than the one who usually followed them, 39.4\% reported that they had teleconsultations, and $91.8 \%$ reported that their partner or a person providing support had not been allowed to attend at least one pregnancy check-up or consultation due to pandemic-related restrictions. In addition, $41 \%$ indicated that they unsuccessfully sought exchanges about the SARS-CoV-2 pandemic and their pregnancy with healthcare professionals.

Of the pregnant women who indicated that they had not started their pregnancy monitoring during the lockdown, the majority (63.7\%) had a gestational age of over 15 weeks, indicating a delay in the management of their pregnancy.

\section{Voluntary changes in pregnancy monitoring}

Just under half of the study sample (48.9\%) reported having at least one consultation or pregnancy check-up postponed or cancelled during the lockdown, whether on their own initiative (23.4\%) and/or the initiative of the hospital and/or a health professional (36.3\%).

The most frequent reasons participants gave for voluntary changes to their pregnancy monitoring were related to the pandemic and lockdown (i.e., fear of being infected with SARS-CoV-2; compliance with restrictions on movement), to personal organisational problems (e.g., caring for other children), and hospital problems (e.g., inability to make an appointment with a health professional) (Fig. 1).

Among women who declared foregoing at least one pregnancy monitoring examination $(n=75)$ as a direct result of the lockdown, almost one-third forewent i) supplementary prescribed or recommended pregnancy monitoring examinations/consultations (31.1\%, Cl95\%[19.8-45.2]) or ii) Trisomy 21 screening (29.2\% [17.1-45.1] regardless of gestational age; $17.4 \%$ [7.9-33.9] before 16 gestational weeks), iii) one in four reported not having monthly toxoplasmosis serology (25.7\%, [14.8-41] (Fig. 2). 
After adjusting for age, gestational age and parity during the first lockdown, being inactive (RPa $=1.98$, CI95\%[1.24-3.16]), having experienced violence (1.47, [1.00-2.16]), having felt little or no support (1.70, [1.07-2.71]), and having changed healthcare professional (1.57, [1.04-2.36]) were all independently and significantly associated with a voluntary change in pregnancy monitoring. Conversely, higher level of worry about the pandemic was inversely associated with voluntary change in pregnancy monitoring $(0.66$ [0.46-0.96]) (Table 2). 
Table 2

Factors influencing the prevalence of voluntary changes in women's pregnancy monitoring during the lockdown period, Covimater survey $(n=500)$, France, 2020

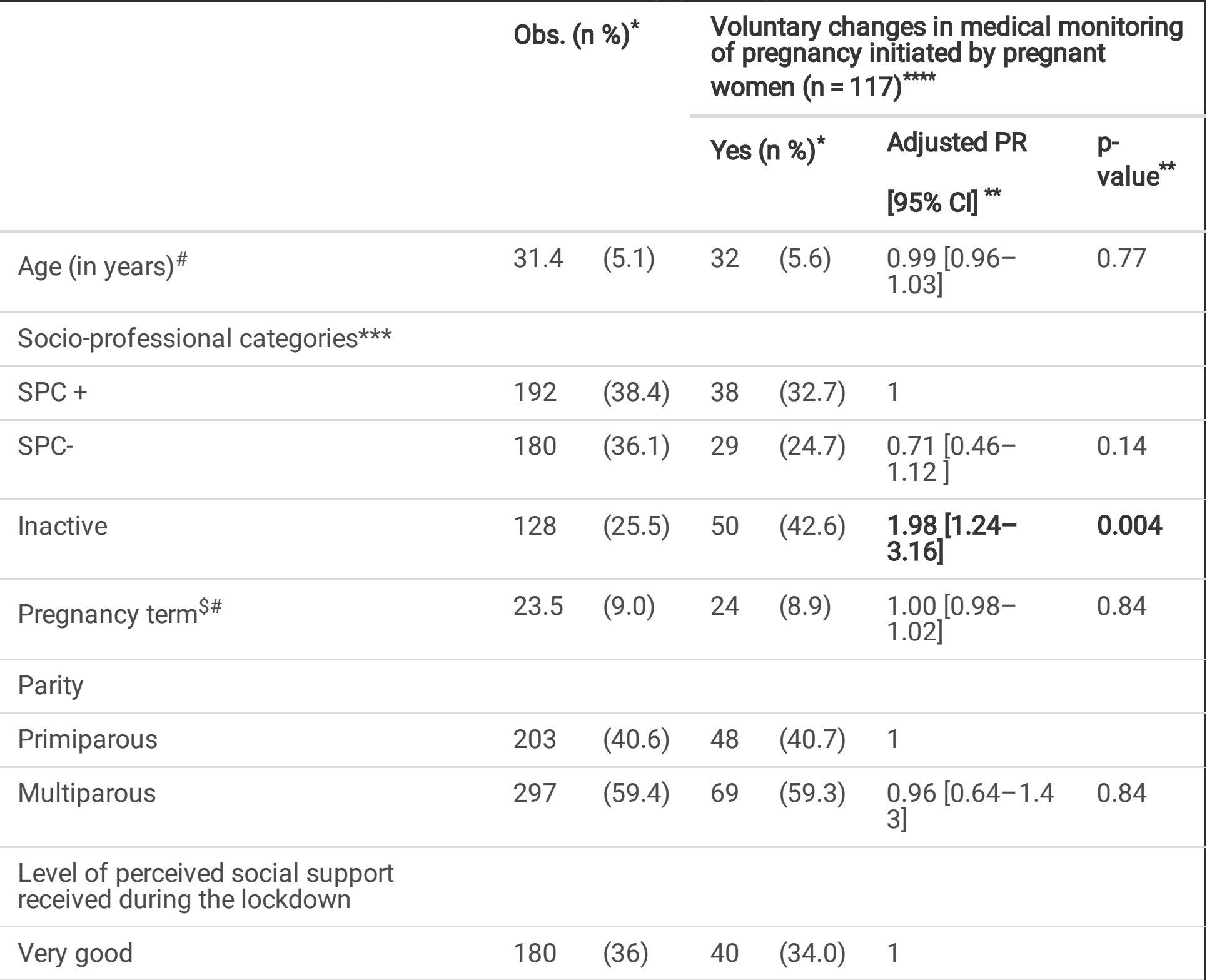

* Weighted and rounded values using Newton's algorithm (26)

** Adjusted Prevalence Ratio (aPR), Confidence Interval 95\% (95\% Cl) with Poisson regression with robust error variance

*** Women on maternity leave and unemployed women were classified according to their current SPC category or their most recent category prior to ending work respectively

* Postponing/foregoing /not starting monitoring despite a gestational age of 15 weeks (see definition of the variable of interest in Methods section).

\$ At the end of the first lockdown (11/05/2020),

$\$ 15$ women did not document their worry score

\# Mean (standard deviation-sd) 


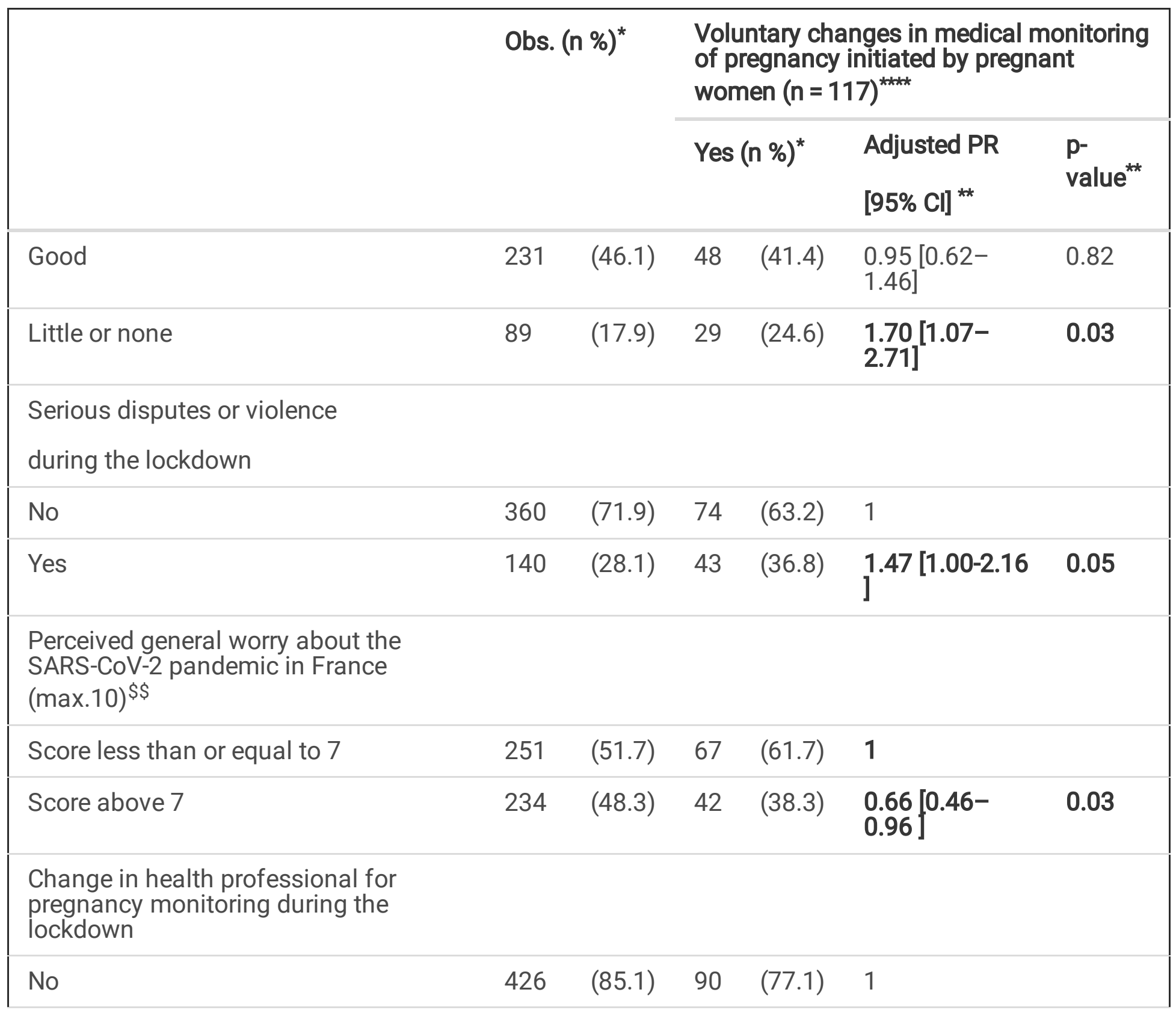

\footnotetext{
* Weighted and rounded values using Newton's algorithm (26)

** Adjusted Prevalence Ratio (aPR), Confidence Interval 95\% (95\% Cl) with Poisson regression with robust error variance
}

*** Women on maternity leave and unemployed women were classified according to their current SPC category or their most recent category prior to ending work respectively

${ }^{\star \star \star *}$ Postponing/foregoing /not starting monitoring despite a gestational age of 15 weeks (see definition of the variable of interest in Methods section).

$\$$ At the end of the first lockdown (11/05/2020),

$\$ 15$ women did not document their worry score

\# Mean (standard deviation-sd) 


\begin{tabular}{|c|c|c|c|c|c|}
\hline & \multirow{2}{*}{\multicolumn{2}{|c|}{ Obs. $(n \%)^{*}$}} & \multicolumn{3}{|c|}{$\begin{array}{l}\text { Voluntary changes in medical monitoring } \\
\text { of pregnancy initiated by pregnant } \\
\text { women }(n=117)^{\star \star \star \star k}\end{array}$} \\
\hline & & & Yes $(n \%)^{*}$ & $\begin{array}{l}\text { Adjusted PR } \\
{[95 \% \mathrm{Cl}]^{* *}}\end{array}$ & $\begin{array}{l}\text { p- } \\
\text { value }^{* *}\end{array}$ \\
\hline Yes & 74 & $(14.9)$ & $27 \quad(22.9)$ & $1.57[1.04-$ & 0.03 \\
\hline \multicolumn{6}{|c|}{ * Weighted and rounded values using Newton's algorithm (26) } \\
\hline \multicolumn{6}{|c|}{$\begin{array}{l}\star \star \\
\text { robust error variance }\end{array}$} \\
\hline \multicolumn{6}{|c|}{$\begin{array}{l}\star \star \star \text { Women on maternity leave and unemployed women were classified according to their current SPC } \\
\text { category or their most recent category prior to ending work respectively }\end{array}$} \\
\hline \multicolumn{6}{|c|}{ 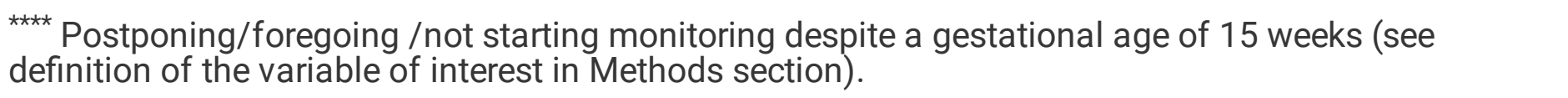 } \\
\hline \multicolumn{6}{|c|}{$\$$ At the end of the first lockdown $(11 / 05 / 2020)$, } \\
\hline \multicolumn{6}{|c|}{$\$ \$ 15$ women did not document their worry score } \\
\hline \# Mean (standard deviation-sd) & & & & & \\
\hline
\end{tabular}

\section{Discussion}

Just under half the study sample (48.9\%) reported at least one consultation or pregnancy check-up being postponed or cancelled during the first lockdown, whether on their own initiative (23.4\%) and/or the initiative of the hospital and/or that of a health professional (36.3\%).

Women who i) were inactive, ii) perceived received little or no social support, iii) experienced violence, and whose iv) healthcare professional changed during the first lockdown, were all significantly more likely to voluntarily change their pregnancy monitoring. Conversely, worry about the pandemic was inversely associated with changing pregnancy monitoring.

Covimater's results show an association between violence and a voluntary change in pregnancy monitoring. The percentage of pregnant women who reported experiencing violence or serious arguments during the first lockdown was high (28.1\%), but significantly lower than that obtained for women of childbearing age (18-49 years) in CoviPrev, a French general population-based repeated cross-sectional study which used the same methodology as Covimater and conducted data-collection waves at the same time (CoviPrev study, $28.1 \%$ vs. $32.9 \%, p=0.03$ ) (33). This result is in line with several studies suggesting that the prevalence of violence on women during pregnancy is no higher than in other situations.

However, there is no international consensus about whether the risk of violence is higher in pregnant 
women than in women who are not pregnant (34-36). Violence during pregnancy not only negatively impacts mothers' health, but also that of their unborn children. It also impacts success of antenatal care $(40,43-45)$. Furthermore, violence is significantly associated with an increased risk of obstetrical complications $(40,43-45)$. In terms of antenatal care, a survey held by the World Health Organisation in Tanzania studying domestic violence on women showed that it was significantly associated with fewer consultations for antenatal care because partners prevented or discouraged women from having them (36). Efforts to detect violence against pregnant women at an early stage must be continued in order to prevent its harmful impact on health (40).

In Covimater, perceiving little or no support during the lockdown was associated with voluntary change in pregnancy monitoring. These results reflect findings from the 2010 French National Perinatal Survey (NPS), where women who declared having no social support were significantly more likely to forego care (41). The perception of receiving little support may have been accentuated by the fact that during the first lockdown, in many maternity hospitals and private practices in France, neither partners nor people providing support to pregnant women were allowed to be present at consultations, obstetrical examinations, and hospitalisation for childbirth, except under certain conditions $(15,18)$ ). Only partners were allowed to visit after childbirth (15).

In our analyses, a change in health professional during the lockdown was associated with a higher likelihood of voluntarily postponing or foregoing pregnancy monitoring. As reported in several studies showing the importance of the patient/caregiver relationship in medical follow-up (in terms of treatment adherence, health examinations, etc.), it seems fundamental to ensure that the monitoring of pregnant women is as personalized as possible in the context of an ongoing pandemic $(42,43)$.

In our study, women who had a higher worry score about the pandemic were less likely to change their pregnancy monitoring. This result suggests the need to communicate with pregnant women with a double objective: i) to avoid any increase in existing worry about the pandemic, and ii) to foster their adherence to health authorities' recommendations concerning uninterrupted pregnancy monitoring. To ensure the quality and regular updating of information received by pregnant women, it is important to involve health care providers so that they can inform or direct their patients to reliable and responsive sources of information (44). French laws for patients' rights and the Public Health Code stipulate that patients have the right to have access to information (45) and that doctors must inform them of advances in science according to their needs (46). Access to reliable information is therefore an essential element in effective patient follow-up.

Finally, in line with Ancelot et al.'s findings in the NPS study in France in 2010 (41), having a chronic illnesses or a pregnancy-related illness was not significantly associated with a voluntary change in pregnancy monitoring in Covimater. Furthermore, participants in Covimater with a deteriorated psychological state during the first lockdown were not more likely to change their pregnancy monitoring than those with no such condition ( $p$-value $=0.89$ ). 
In addition to characterising women with a higher prevalence of modifying their pregnancy monitoring during the first COVID-19-related lockdown in France, our study also aimed to stress the reasons for these voluntary postponements or waiving of care. In addition to those related to the pandemic (i.e., fear of being infected by SARS-CoV-2, compliance with restrictions on movement), some of these reasons were organisational in nature, whether related to healthcare provision, or personal organisation problems linked to the pandemic. In Covimater, $28.6 \%, 17.7 \%$ and $15.3 \%$ declared, respectively, that they had not managed to make an appointment, that they had not been able to contact the health professional who usually followed them, or that it had been impossible for them to take days off work to attend their pregnancy appointments. Despite French authorities' recommendations to promote video and telephonebased consultations when possible outside of the three compulsory ultrasounds requiring physical presence, a relatively large proportion of women were unable to contact healthcare structures, and as a consequence, modified their pregnancy monitoring (15,53-55). In terms of personal organisation of healthcare schedules, discussions are currently underway at the national level to provided current and future parents with greater flexibility to better reconcile their professional and parenthood (50).

\section{Strengths and limitations}

To the best of our knowledge, Covimater is the first national study in France to explore the experiences and behaviours of pregnant women during the SARS-CoV-2 pandemic. It used the same methodology as another study conducted in France at the same time on the general population entitled Coviprev. This choice was made to ensure comparison with women of childbearing age. Unlike studies from other countries which mostly focused on the third trimester of pregnancy during the current pandemic, Covimater included women with different gestational ages.

Covimater has some limitations. First, the probability of inclusion of individuals from the whole population of pregnant women in France was unknown. Consequently, greater caution is required when interpreting the statistical inference than would be needed for random sample studies. Second, sampling bias could explain the overestimation of the percentage of pregnant women with pre-existing chronic diseases or obesity. Third, as the study questionnaire was self-administered, there is always the risk that respondents misunderstood or misinterpreted questions and a risk of potential social desirability and recall biases. However, there is no reason to suppose that either of these biases should be limited to the particular sub-group of pregnant women who had postponed/forgone their pregnancy monitoring.

\section{Conclusion}

The results of this study highlight the importance of defining strategies to prevent voluntary changes in pregnancy monitoring among women in difficult social situations (isolation, violence), which may be accentuated by the ongoing COVID-19 pandemic. In addition, it is necessary to increase access to teleconsultations and provider-patient communication channels during pandemics. Despite the continued difficulties that countries around the world are still facing, this period provides an unprecedented opportunity for maternity units and hospitals to rethink their organisations and reinforce access to care 
for future health crises and ensure effective and efficient follow-up of pregnant women. One possible strategy - currently being discussed at the national level - is to coordinate all concerned professionals around a reference person (50).

\section{Declarations}

\section{Ethics approval and consent to participate}

Covimater received approval from the Saint Maurice Hospital Ethics Committee on 01/07/2020 (approval number $n^{\circ}$ 2020-1). We confirm that the Internet panel volunteers, included in the Covimater study, were informed of the purpose of the study at the time of their inclusion, then they were free to participate or not in the survey. No subjects under 18 were included in the study. Only pseudonymised databases were transmitted to Santé Publique France.

\section{Consent for publication}

Only aggregated data is reported in this article. No personal information appears in this article.

\section{Availability of data and materials}

The datasets generated and/or analysed during the current study are not publicly available due privacy or ethical restrictions but are available from the corresponding author on reasonable request.

\section{Competing Interests}

The authors declare that they have no competing interests.

\section{Funding}

This work was entirely financed by public funds.

\section{Authors' contributions}

A.D., L.A. and N.R. conceived of the presented idea. L.A. and A.D. developed the theory and performed the computations. N.R. verified the analytical methods. All authors discussed the results and contributed to the final manuscript.

\section{Acknowledgments}

We would like to thank Dorothée Lamarche (BVA Institute) for her valuable help in developing the questionnaire and Jude Sweeney (Milan, Italy) for the English revision and editing of this manuscript.

\section{References}


1. Jamieson DJ, Ellis JE, Jernigan DB, Treadwell TA. Emerging infectious disease outbreaks: Old lessons and new challenges for obstetrician-gynecologists. Am J Obstet Gynecol. 1 juin 2006;194(6):1546-55.

2. Schwartz, D. A., \& Graham, A. L. Potential Maternal and Infant Outcomes from (Wuhan) Coronavirus 2019-nCoV Infecting Pregnant Women: Lessons from SARS, MERS, and Other Human Coronavirus Infections. 2020;12(2). Disponible sur: doi:/v12020194

3. Peyronnet V, Sibiude J, Deruelle P, Huissoud C, Lescure X, Lucet JC, et al. Infection par le SARS-CoV-2 chez les femmes enceintes: état des connaissances et proposition de prise en charge par CNGOF. Gynécologie Obstétrique Fertil Sénologie. 1 mai 2020;48(5):436-43.

4. Monteleone PA, Nakano M, Lazar V, Gomes AP, de Martin H, Bonetti TC. A review of initial data on pregnancy during the COVID-19 outbreak: implications for assisted reproductive treatments. JBRA Assist Reprod. 2020;24(2):219-25.

5. Centers for Disease Control and Prevention. Covid-19 and pregnancy. 2020;

6. Haut Conseil de la santé publique (HCSP). Actualisation de l'avis relatif aux personnes à risque de forme grave de Covid-19 et aux mesures barrières spécifiques à ces publics [Internet]. 2020. Disponible sur: https://www.hcsp.fr/explore.cgi/avisrapportsdomaine?clefr=807

7. Public Health Agency of Canada. Coronavirus disease (covid-19)pregnancy, childbirth and caring for newborns: advice for mothers during covid-19. 2020;

8. Public Health England (PHE). Guidance on social distancing for everyone in the UK. 2020.

9. Coronavirus: People at especially high risk [Internet]. Disponible sur: https://www.bag.admin.ch/bag/en/home/krankheiten/ausbrueche-epidemien-pandemien/aktuelleausbrueche-epidemien/novel-cov/krankheit-symptome-behandlung-ursprung/besondersgefaehrdete-menschen.html

10. The American College of Obstetricians and Gynecologists. COVID-19 Obstetric Preparedness Manual [Internet]. Washington; 2020 avr. Disponible sur: https://www.acog.org/-/media/project/acog/acogorg/files/pdfs/education/covid-19-obstetricpreparedness-manual.pdf

11. Royal College of Obstetricians and Gynaecologists, Royal College of Midwives. Guidance for antenatal and postnatal services in the evolving coronavirus (COVID-19) pandemic. London; 2020 avr.

12. Tschann M, Ly ES, Hilliard S, Lange HLH. Changes to medication abortion clinical practices in response to the COVID-19 pandemic. Contraception [Internet]. 21 avr 2021 [cité 26 avr 2021]; Disponible sur: https://www.sciencedirect.com/science/article/pii/S0010782421001153

13. Bradley D, Blaine A, Shah N, Mehrotra A, Gupta R, Wolfberg A. Patient Experience of Obstetric Care During the COVID-19 Pandemic: Preliminary Results From a Recurring National Survey. J Patient Exp. oct 2020;7(5):653-6.

14. Jouen T, Gauthier T, Azais H, Bendifallah S, Chauvet P, Fernandez H, et al. The impact of the COVID19 coronavirus pandemic on the surgical management of gynecological cancers: Analysis of the 
multicenter database of the French SCGP and the FRANCOGYN group. J Gynecol Obstet Hum Reprod. 28 mars 2021;50(8):102133.

15. Kayem G, Lecarpentier E, Deruelle P, Bretelle F, Azria E, Blanc J, et al. A snapshot of the Covid-19 pandemic among pregnant women in France. J Gynecol Obstet Hum Reprod. 4 juin 2020;101826.

16. Group BMJP. Covid-19 and pregnancy. BMJ. 4 mai 2020;369:m1672.

17. Code de la santé publique - Article R6123-50, décret n²010-344 du 31 mars 201-art181. 1 avril 2010 mars 2010. Code de la santé publique.

18. Dobrzyński M-LD. Naissance en temps de Covid 19. Rech Éducations [Internet]. 11 mai 2020 [cité 19 avr 2021];(HS). Disponible sur: http://journals.openedition.org/rechercheseducations/11353

19. Verweij EJ, M'hamdi HI, Steegers EAP, Reiss, IKM, Schoenmakers1 S. Collateral damage of the covid19 pandemic: a Dutch perinatal perspective [Internet]. 2020. Disponible sur: http://dx.doi.org/10.1136/bmj.m2326

20. Suivi et orientation des femmes enceintes en fonction des situations à risque identifiées [Internet]. Haute Autorité de Santé. [cité 4 mai 2021]. Disponible sur: https://www.hassante.fr/jcms/c_547976/fr/suivi-et-orientation-des-femmes-enceintes-en-fonction-des-situations-arisque-identifiees

21. Effect of Treatment of Gestational Diabetes Mellitus on Pregnancy Outcomes | NEJM [Internet]. [cité 19 avr 2021]. Disponible sur: https://www.nejm.org/doi/full/10.1056/NEJMoa042973

22. Ferrara A, Hedderson MM, Brown SD, Ehrlich SF, Tsai A-L, Feng J, et al. A telehealth lifestyle intervention to reduce excess gestational weight gain in pregnant women with overweight or obesity (GLOW): a randomised, parallel-group, controlled trial. Lancet Diabetes Endocrinol. juin 2020;8(6):490-500.

23. Goldstein RF, Abell SK, Ranasinha S, Misso M, Boyle JA, Black MH, et al. Association of Gestational Weight Gain With Maternal and Infant Outcomes: A Systematic Review and Meta-analysis. JAMA. 6 juin 2017;317(21):2207-25.

24. Bah AO, Diallo AAS, Keita N, Diallo MS. Hypertension arterielle et grossesse aspects epidemiologiques et facteurs de risques. Médecine d'Afrique Noire. 47(10):422-5.

25. French National Institute of Statistics and Economic Studies [Internet]. Disponible sur: https://www.insee.fr/en/information/2107702

26. Deville J-C, Särndal C-E. Calibration Estimators in Survey Sampling. J Am Stat Assoc. 1 juin 1992;87(418):376-82.

27. Piffaretti C, Looten V, Rey S, Fresson J, Fagot-Campagna A, Tuppin P. Management of pregnancy based on healthcare consumption of women who delivered in France in 2015: Contribution of the national health data system (SNDS). J Gynecol Obstet Hum Reprod. sept 2018;47(7):299-307.

28. Ministry of health. Coronavirus COVID-19: Carte du déconfinement en France. 2020.

29. Barros AJD, Hirakata VN. Alternatives for logistic regression in cross-sectional studies: an empirical comparison of models that directly estimate the prevalence ratio. BMC Med Res Methodol. 20 oct 
2003;3(1):21.

30. Zou G. A modified poisson regression approach to prospective studies with binary data. Am J Epidemiol. 1 avr 2004;159(7):702-6.

31. Chapitre ler: Diagnostics anténataux: diagnostic prénatal et diagnostic préimplantatoire. (Articles L2131-1 à L2131-5) - Légifrance [Internet]. [cité 5 mai 2021]. Disponible sur:

https://www.legifrance.gouv.fr/codes/id/LEGISCTA000024325447/2011-07-09

32. Article L2131-4 - Code de la santé publique - Légifrance [Internet]. [cité 5 mai 2021]. Disponible sur: https://www.legifrance.gouv.fr/codes/article_Ic/LEGIARTI000024325453/

33. Raude J, Lecrique J-M, Lasbeur L, Leon C, Guignard R, du Roscoät E, et al. Determinants of Preventive Behaviors in Response to the COVID-19 Pandemic in France: Comparing the Sociocultural, Psychosocial, and Social Cognitive Explanations. Front Psychol [Internet]. 2020 [cité 19 avr 2021 ];11. Disponible sur: https://www.frontiersin.org/articles/10.3389/fpsyg.2020.584500/full

34. Campbell J, García-Moreno C, Sharps P. Abuse During Pregnancy in Industrialized and Developing Countries. Violence Women. 1 juill 2004;10(7):770-89.

35. Findings About Partner Violence From the Dunedin Multidisciplinary Health and Development Study, Research in Brief [Internet]. National Institute of Justice. [cité 3 mai 2021]. Disponible sur: https://nij.ojp.gov/library/publications/findings-about-partner-violence-dunedin-multidisciplinaryhealth-and

36. Stöckl H, Watts C, Kilonzo Mbwambo JK. Physical violence by a partner during pregnancy in Tanzania: prevalence and risk factors. Reprod Health Matters. nov 2010;18(36):171-80.

37. Hill A, Pallitto C, McCleary-Sills J, Garcia-Moreno C. A systematic review and meta-analysis of intimate partner violence during pregnancy and selected birth outcomes. Int J Gynaecol Obstet Off Organ Int Fed Gynaecol Obstet. juin 2016;133(3):269-76.

38. Silverman JG, Decker MR, Reed E, Raj A. Intimate partner violence victimization prior to and during pregnancy among women residing in 26 U.S. states: Associations with maternal and neonatal health. Am J Obstet Gynecol. 1 juill 2006;195(1):140-8.

39. Sigalla GN, Mushi D, Meyrowitsch DW, Manongi R, Rogathi JJ, Gammeltoft T, et al. Intimate partner violence during pregnancy and its association with preterm birth and low birth weight in Tanzania: $A$ prospective cohort study. PloS One. 2017;12(2):e0172540.

40. Cillart L. Les sages-femmes dans le dépistage des violences conjugales: état des lieux des pratiques en Auvergne. Médecine humaine et pathologie [Internet]. 2016; Disponible sur: https://dumas.ccsd.cnrs.fr/dumas-01535762

41. Déterminants du renoncement aux soins des femmes durant leur grossesse | Cairn.info [Internet]. [cité 19 avr 2021]. Disponible sur: https://www.cairn.info/revue-francaise-d-economie-2016-4-page63.htm? contenu=resume

42. La relation de soin, concepts et finalités | Cairn.info [Internet]. [cité 3 mars 2021]. Disponible sur: https://www.cairn.info/revue-recherche-en-soins-infirmiers-2007-2-page-33.htm 
43. La relation thérapeutique: enquête sur l'état de la recherche [*] | Cairn.info [Internet]. [cité 3 mars 2021]. Disponible sur: https://www.cairn.info/revue-approche-centree-sur-la-personne-2014-1-page58.htm

44. Javanmardi M, Noroozi M, Mostafavi F, Ashrafi-rizi H. Internet Usage among Pregnant Women for Seeking Health Information: A Review Article. Iran J Nurs Midwifery Res. 2018;23(2):79-86.

45. LOI n 2002-303 du 4 mars 2002 relative aux droits des malades et à la qualité du système de santé (1) - Légifrance [Internet]. [cité 4 mai 2021]. Disponible sur: https://www.legifrance.gouv.fr/jorf/id/JORFTEXT000000227015/

46. Article L1142-1 - Code de la santé publique - Légifrance [Internet]. [cité 4 mai 2021]. Disponible sur: https://www.legifrance.gouv.fr/codes/article_Ic/LEGIARTI000020628252/

47. Réponses rapides dans le cadre du COVID-19 -Téléconsultation et télésoin [Internet]. Haute Autorité de Santé. [cité 19 avr 2021]. Disponible sur: https://www.has-sante.fr/jcms/p_3168867/fr/reponsesrapides-dans-le-cadre-du-covid-19-teleconsultation-et-telesoin

48. Alexandre J. Vivanti, Chloé Barasinskic,k, Olivier Piconeb,j, Sophie Guillaumec, Jean-Christophe Rozed, Blandine Muline, et al. Follow-up for pregnant women during the COVID-19 pandemic: French national authority for health recommendations. J Gynecol Obstet Hum Reprod [Internet]. 49(7). Disponible sur: https://doi.org/10.1016/j.jogoh.2020.101804

49. Haute Autorité de Santé. GROSSESSE Votre suivi pendant l'épidémie de Covid-19 [Internet]. 2020 nov. Disponible sur: https://www.has-sante.fr/upload/docs/application/pdf/2020-05/grossesse__votre_suivi_pendant_lepidemie_de_covid-19_2020-05-29_14-53-17_577.pdf

50. Les 1000 premiers jours: Là où tout commence [Internet]. 2020 sept. Disponible sur: https://solidarites-sante.gouv.fr/IMG/pdf/rapport-1000-premiers-jours.pdf

\section{Figures}

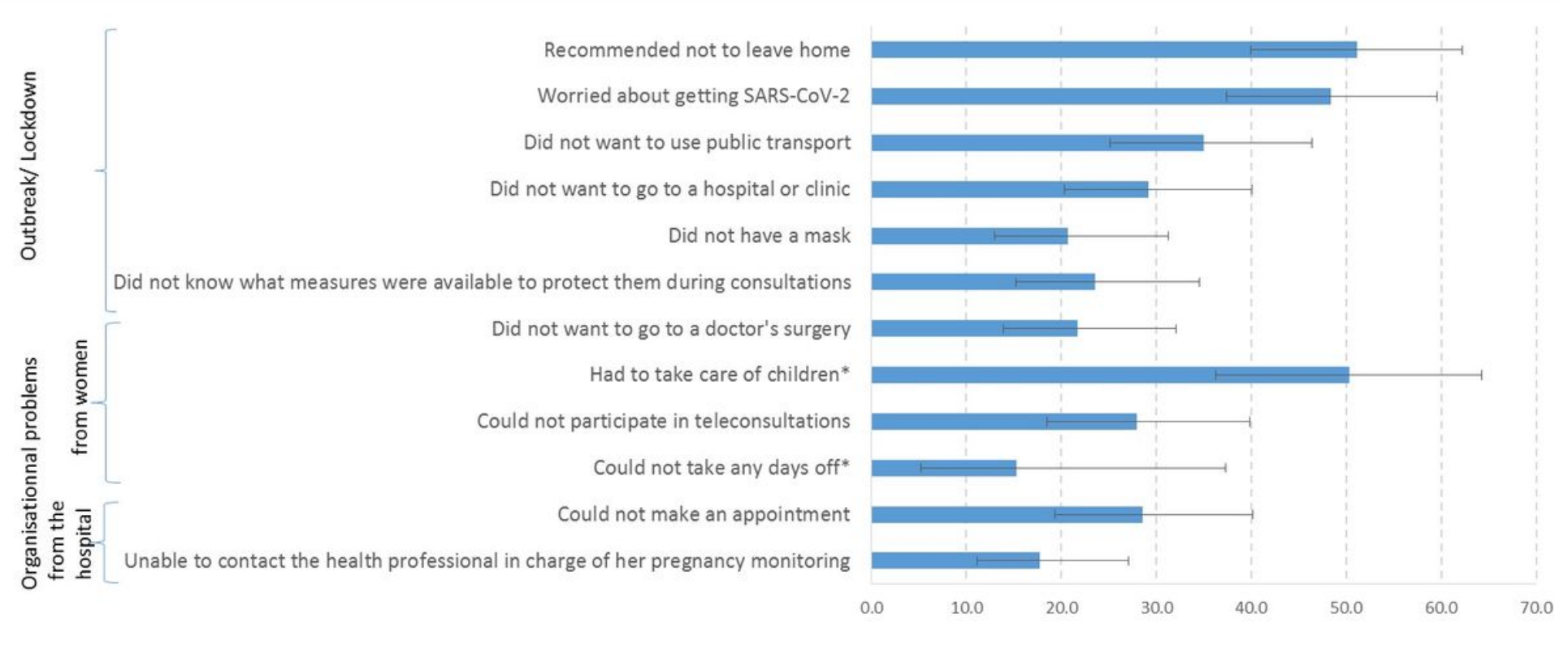


Figure 1

Reasons given by pregnant women to explain a voluntarily change\$ in their pregnancy monitoring during lockdown, Covimater survey; Women who changed their pregnancy monitoring ( $n=107)$, metropolitan France, 2020 Percentage (\%) of women who had voluntarily postponed/forgone their pregnancy monitoring *Analysis carried out in a subgroup of women (who had children or who were working during the lockdown) \$ : Postponing/foregoing /not starting monitoring despite a gestational age of 15 weeks (see definition of the variable of interest in Methods section). Available data $(n=107)$

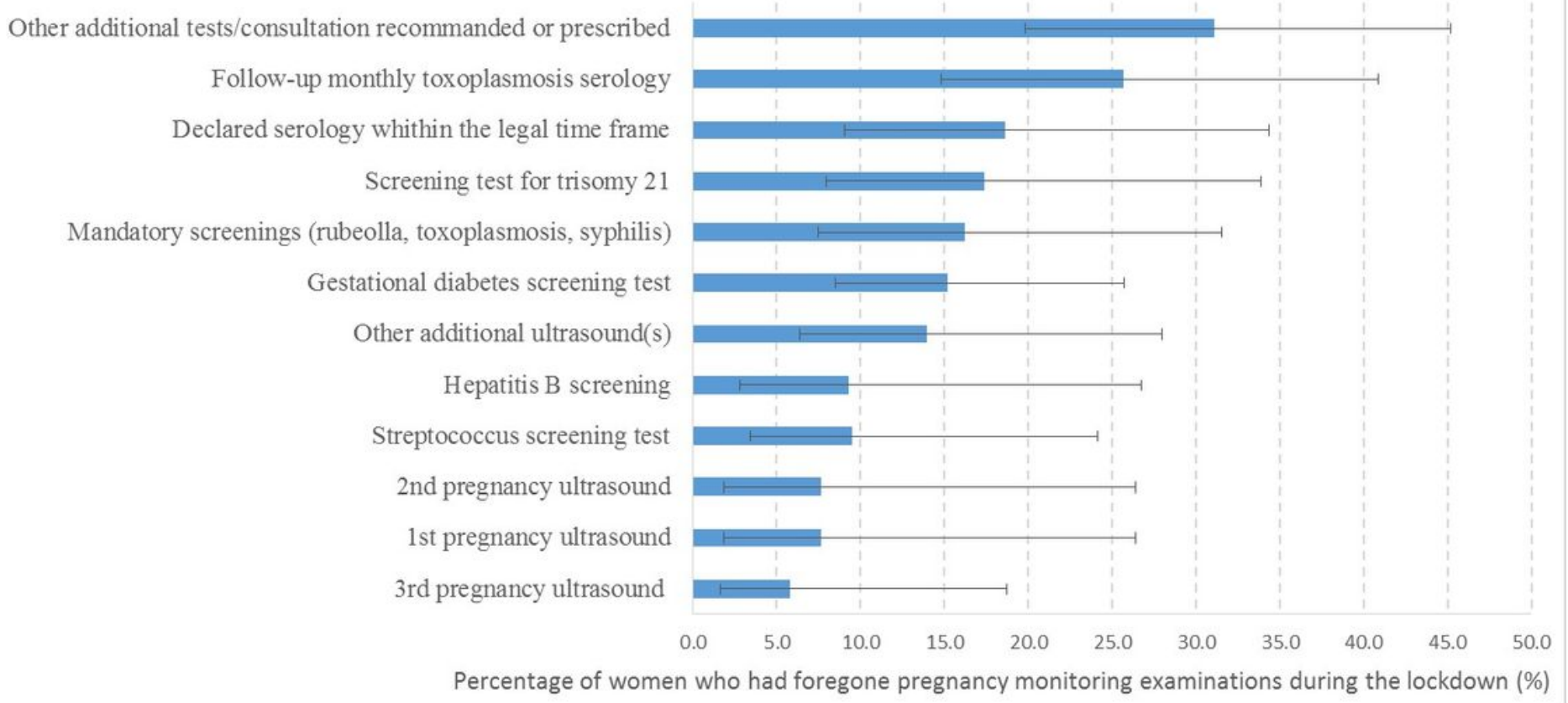

\section{Figure 2}

Foregoing of pregnancy monitoring examinations during the lockdown, Covimater survey; $(n=75)$, metropolitan France, 2020 